\title{
THE WAR IN LEON AND CASTILE (CA. 1110-1130). INTERNAL CRISIS AND IMAGINARY OF VIOLENCE
}

\author{
Pascual Martínez Sopena \\ UNIVERSIDAD DE VALLADOLID \\ SPAIN
}

Date of receipt: $29^{\text {th }}$ of October, 2013

Final date of acceptance: $10^{\text {th }}$ of September, 2014

\section{Abstract}

This article deals with an aspect of the deep social crisis occurred in Leon and Castile during the time of Queen Urraca (regnante 1109-1126), the heir of Alfonso VI (regnante 1066/1072-1109). It was a period of war, which even continued after the death of the queen, during the first years of the reign of her son and heir, Alfonso VII (regnante, 1126-1157). The paper does not aim to describe the course of a war in the $12^{\text {th }}$ century. It asks, however, questions about the dynamics of the war. To do so, we look at its material, social and symbolic items throughout a series of pictures from various sources. ${ }^{1}$

\section{Keywords}

Castile and Leon, Social History, $12^{\text {th }}$ Century, War, Way of Saint James.

\section{Capitalia Verba}

Castella et Legio, Historia Socialis, Saeculum XII, Bellum, Iter Sancti Iacobi. 
Alfonso VI died in 1109. He had ruled León and Castile for almost forty years. During the first stage of his rule, his kingdoms spread over the valleys of the great rivers of the Iberian Peninsula: the Ebro Valley, with the incorporation of La Rioja (1076), that had been part of the kingdom of Pamplona [Navarre]; the Douro Valley, by dominating the area south of the river (the Extremaduras) in the 1080s; and the Tagus Valley, with the conquest of the city of Toledo, the key to al-Andalus (1085).

However, only one year later, in autumn 1086, the Almoravids came to the aid of the Muslims of Spain, defeating Alfonso VI's army in the battle of Zalaca. The Almoravids held a certain rigorist view of Islam and their social base was Berbers from the Sahel; they had founded Marrakech and dominated the northwest of Africa. Their victory marked the start of a new stage, this being the first of a series of defeats for the Christians that culminated in 1108. That year, Prince Sancho, the king's son and heir, died in the district of Uclés, on the Tagus, together with various counts and their retinues. Shortly after, al-Andalus was incorporated into the Almoravid Empire.

Despite this, the balance of the period was not disastrous for the Christians. The Castilian-Leonese society faced the challenges - like other parts of the northern Peninsula. Internal growth was maintained and there were profound institutional changes. Notable among these was ecclesiastical reform. This began during the pontificate of Gregory VII and with the support of Alfonso VI, and it introduced an arsenal of rites, norms and standards for living that changed the Church in the kingdom in the latter decades of the $11^{\text {th }}$ century. These are also associated with the enrichment of monasteries and cathedrals. Simultaneously, the notion of "nobility" was defined in a similar sense to the one that was taking root all over the West. However, the traditional practices of dividing the inheritance between all the sons persisted. This suggests a nobility made up of large cognate kinships, and helps to explain the central role of the monarchy as a distributor of benefits.

On the other hand, between 1088 and 1110 , the leading cities and towns of the Douro valley and the Extremaduras -Zamora and Toro, Segovia, Medina del Campo and Ávila, Salamanca and Alba de Tormes were consolidated. Their success was due to their role as a defensive shield for the kingdom against the Almoravid menace. However, in the cities in the rearguard, like León, Oviedo or Burgos, something similar is seen. The rise of the Way of Saint James represents one of the most active aspects of the growth that is seen during Alfonso VI's reign. One must think that the monarchy, with the collaboration of nobles, abbots and bishops, promoted the traditional urban centres and favoured the birth of new ones.

Together, these elements explain the accumulation of internal tensions that burst out after the king's death, in a political crisis that has also been interpreted as a crisis of growth.

Alfonso VI was succeeded by his daughter Urraca. The new queen was a widow. Her late-husband, Raimundo, was a nephew of Abbot Hugo of Cluny and had

1. This work is part of the Research Project "Poderes, espacios y escrituras en los reinos hispánicos occidentales (siglos XI-XIV)" (HAR2013-42925-P), financed by the 'Ministry of Economy and Competitiveness of the Government of Spain. 
arrived in Spain in the 1080s. Second son of the Dukedom of Burgundy, he reached the highest honours in the Leonese court. He was made Count of Galicia and also put in charge of settling the main cities of the Extremaduras. Effectively supported by his cousin Henry of Portugal - the husband of another of Alfonso VI's daughters, Infanta Teresa-, he had risen to be the arbiter of policy in the kingdom, but had died in 1107.

The Queen has been particularly badly treated by posterity. In contrast, her most recent biographers have emphasised that "no es nada difícil encontrar decisiones enérgicas, en la experiencia vital o en la acción política de esta mujer". ${ }^{2}$ It should be borne in mind that her son Alfonso Raimúndez, tutored by the bishop of Compostela Diego Gelmírez and Count Pedro Froilaz, lived in Galicia, among old collaborators of her father who mistrusted her. Count Henry and his wife also organised their own party in Portugal. With the backing of a sector of the nobility, Urraca remarried, this time to Alfonso el Batallador, king of Aragon and Pamplona. However, the marriage became a new problem: new factions formed around each spouse. Many members of the nobility, bishops and abbots from León and Castile remained loyal to the Queen. On the other hand, el Batallador had a great deal of support in the cities and towns.

The crisis was already brewing in 1110 and continued after Urraca's death in 1126, during the first years of her successor, the above-mentioned Alfonso [VII] Raimúndez. ${ }^{3}$ Only after Alfonso el Batallador's troop abandoned Castrogeriz, their last base in the heart of Castile (1131), did this come to an end.

This study focuses on these twenty years. It is a coherent period for approaching various aspects of a profound social crisis that manifested itself through permanent conflict. The leading scenarios were the lands in the great northwest of Spain, structured around the Way of Saint James in that epoch. However, it is well known that there were other war zones in these times. Foremost among these, the "hot frontier" with al-Andalus poses a distinct problem. There, Muslims and Christians waged a much longer war: it had broken out in the 1080s and its early phases lasted until the start of the $13^{\text {th }}$ century. Nor did participants on the two sides coincide -Almoravids then Almohads on one side, pardos (brown) knights of the frontier concejos or councils on the other.

The purpose of this contribution is not to describe the actions in a $12^{\text {th }}$-century war. Instead, what has been researched is the dynamic of the war, highlighting its

2. "It is not at all difficult to find energetic decisions, in the experience or the political action of this woman," The oldest chronicles were written by men of the Church and include well-known stereotypes about the female condition. See particularly Falque, Emma, ed. Historia Compostellana. Turnhout: Brepols, 1988. About the queen's personality, Reilly, Bernard F. The Kingdom of León-Castilla under Queen Urraca (1109-1126). Princeton: Princeton University Press, 1982; Pallares, Maria del Carmen; Portela, Ermelindo. La reina Urraca. San Sebastian: Nerea, 2006 (the quote is from the latter book, page 187).

3. In 1126, shortly after rising to the throne, Alfonso VII went to the monastery of Sahagún to seek pardon for the harm he and his supporters had caused there during the previous seventeen years of "crude war"; the diploma in which he manifested his contrition was placed on the altar of Saints Facundo and Primitivo, the monastery's patrons, according to a ritual of the Cluniac tradition. Fernández, José Antonio, ed. Colección Diplomática del monasterio de Sahagún (857-1230). IV (1110-1199). Leon: Centro de Estudios e Investigación 'San Isidoro', 1991: IV, 103-106 (doc. No. 1226). 
material, social and symbolic components through a series of aspects from a range of sources. In the first, the measures adopted to finance the campaigns are examined, centred round the trail left by the requisitions by Queen Urraca and her agents in the surviving documents from the royal chancellery. The second emphasises the dimensions of a struggle that involved society as a whole, with attention to the variety and eventual exchange of roles among the participants. A range of narrative sources is the main base for this section. The third starts from a collateral episode (the marriage negotiations of the young King Alfonso VII reflected in the outline of the official history), to reflect on how the troops who joined the host and the propitiatory acts marked out the march of an army towards the enemy. The fourth and last section focuses on explaining a revolt of a local nature. Apart from a brief archaeological notice, it indicates how the description of the fate of the losers suggests habitual practices.

\section{Seeking resources for the war}

The Historia Compostelana tells that doña Urraca donated the realengo and infantazgo situated between the rivers Tambre and Ulla to Santiago Cathedral, as well as property in Santiago itself and some villages. This took place around 1112. This fortunate event strengthened the lordship that the apostolic see exercised over the territory. At the same time, it reinforced the loyalty of the bishop and chapter to the sovereign. However, another circumstance is visible. The Queen lacked the resources required to face a new campaign against Alfonso el Batallador, as she had already spent almost all the treasure accumulated by her father in the previous ones. The bishop and canons decided that they "no debía negarse a la reina el [nuevo] auxilio ni el consejo que había solicitado a la iglesia [de Compostela]". "Así pues, ordenaron por propia iniciativa que se dieran a la reina... cien onzas de oro y doscientas marcas de plata del tesoro de Santiago, para luchar contra el peor devastador de España y poner en fuga al perturbador de todo el reino". ${ }^{4}$

The Queen had approached the basilica to request the protection of the Apostle against the misfortunes that afflicted the country. She asked for the prayers of the priests, showing herself generous. The canons acted knowing her plan to restart the war and her penury; moreover their own duties of auxilium and consilium obliged them to the Queen. There remains doubt about whether the events took place as they were recorded, combining the awareness of the sacred with the duties of royal allegiance. In contrast, it is evident that this episode illustrates a certain general dynamic. The war between Urraca and her husband had devoured Alfonso

4. (The bishop and canon decided that) "the queeen should not be denied the [new] assistance, or the advice that she had requested from the church [of Compostela]". "They thus ordered, on their own iniciative, that the queen should be given.... one hundred gold onzas and two hundred silver marcas from the treasury of Santiago, to fight against the worst devastation of Spain and put to fight those disrupting the entire kingdom": Historia Compostellana...: 92-93. 
VI's treasure in less than two years. It was necessary to resort to the treasures of the ecclesiastic institutions. These had been fed by the long epoch of seigniorial expansion and deep reforms, the good climate of understanding among the powerful, and an atmosphere of authority and peace. Moreover, the Compostela see added its character as the destination of the great Jacobean pilgrimage. This meant constant income from the alms and intense commercial activity. In contrast, the Queen had to renounce a considerable royal patrimony, donating it to cathedrals and monasteries. Generally, these were land and rural and urban property, as well as villages (hereditates and villas). Due to her condition, Urraca had a very wide and complex set of goods and rights (the so-called realengo), and could dispose of the infantazgo (the goods ceded to the daughters of the kings discretely consecrated to God; among these elements, the monasteries of the royal kin stood out).

The documentation in the Queen's chancellery tells us about the range of practices that surrounded this argument, while also suggesting two phases of the requisitions, each with its own scenario..$^{5}$ As well as the cathedral in Compostela, the monastery of Samos and the cathedrals of Mondoñedo, Oviedo and Lugo supply data about an initial phase covering the $1111-1112$ period. ${ }^{6}$ The evidence is found in the northern parts of the realm, Asturias and Galicia. In contrast, almost all later evidence is from the western regions of the Meseta of the Douro. At least between 1114 and 1124, the Queen and her officials obtained resources in the sees of Palencia, León and Astorga, and the monasteries of Husillos, San Juan de Baños and Valcabado.7 This geographic split in the requisitions suggests that the Queen sought refuge in the lands on the Atlantic at the start of the crisis; her husband then controlled the centre of the kingdom. Later, doña Urraca consolidated her positions in this area; but the faction of her son Alfonso Raimúndez must have slowed her activity almost all over Galicia.

Several of the institutions mentioned were repeatedly approached. While, as is seen, Samos was approached in 1112 and 1120, the treasure of the little monastery of Valcabado was ravaged in 1115 and 1116 (and perhaps earlier in 1112), as was that of Palencia Cathedral, at least in 1114 and before 1124, and the one in León, in 1116,1118 and around 1122 . The reiteration of the events does not differ greatly from the tone Alfonso VII used when he proposed to compensate the monastery of Sahagún for being sacked, or that of the Primer Anónimo, when referring to the

\footnotetext{
5. Ruiz, Irene. La reina doña Urraca (1109-1126) Cancillería y colección diplomática. Leon: León Centro de Estudios e Investigación "San Isidoro", 2003. The around twenty diplomas on this type of operations make up $15 \%$ of the known documents from the royal chancellery: a considerable figure, a sign of the derivations of the affair. The number of royal diplomas from this period is much smaller than in earlier or later times. Furthermore, this type of documentation is exclusive to Urraca's reign. On the other hand, it is reasonable to think that the list of institutions approached and volume of the demands was much higher.

6. Ruiz, Irene. La reina doña Urraca...: $397-398$ (doc. No. 27), 398-405 (doc. No. 28), $412-414$ (doc. No. 33) and 415-418 (doc. No. 35).

7. Ruiz, Irene. La reina doña Urraca...: 445-447 (doc. No. 57), 450-452 (doc. No. 60), $473-475$ (doc. No. 76), 483 (doc. No. 81), 498-500 (doc. No. 92), 529-532 (doc. No. 109), 539-542 (doc. No. 115), 555-558 (doc. No. 125), 558-559 (doc. No. 126) and 580-582 (doc. No. 141).
} 
continuous demands from Alfonso el Batallador's followers in the same place. So the concentration of news in certain centres does not indicate the number of those plundered, but is rather a symptom of the long process of plunder that the religious houses suffered, and that only a few of them have conserved the record.

However, the task to solving doña Urraca's needs did not depend solely on the institutions of the Church. The archdeacon of Oviedo presented a valuable cup to the Queen in 1112, while the cathedral was stamping its treasure. One must imagine other dignitaries from the see itself acting similarly, or replicas of this type in the other chapters. The laity also contributed to the cause. Little is known about them, given the few surviving documents not in ecclesiastic hands. The most clearly identified people are count Froila Díaz and his wife Estefanía, Bermudo Pérez and Diego Fernández, for whom we have information about their contributions in 1112 1113, and that vouches for the hold Urraca's supporters had among the nobility. ${ }^{8}$

In the same line as the episode in the Historia Compostelana, there are diplomas that justify the requisitions through the need to defend the realm against "the invaders" or "the foreign people". However, attacks by the "counts of the land" are also reported. The local scale of the war between factions is perceived in this, while certain beneficiaries of the crisis are identified. ${ }^{9}$ Although the Queen mainly granted lands and changes of tenure, she also occasionally confirmed fiscal privileges, or returned property and rights seized some time earlier to their rightful owners. The value of some of these compensations generates doubts, more than the sum obtained by doña Urraca. ${ }^{10}$

In any case, all the operations together reveal that the Queen gathered both cash and valuables. The quantities of gold and silver coinage stand out, and these were eventually identified by their Islamic or Pyrenean origin. These are "dinares" and "dirhemes" described as auri purissimi metcales and solidi purisimo pondere maurisco, or solidorum iaccensis monete. Less precisely, the solidos de denarios could denote local mintings and copper coins. However, it is common for the metal to appear valued by weight (pondere pessato) in marcas or marcos of silver and uncias or ounces of gold. Apart from this, a range of objects made of precious metals is described: goblets and cups, cutlery and pieces of crockery, some rings and certain pieces of riding

8. Ruiz, Irene. La reina doña Urraca...: $405-407$ (doc. No. 29), $423-424$ (doc. No. 39), 431 (doc. No. 46), 435 (doc. No. 50) and 457-459 (doc. No. 65) (see also foot note 34).

9. Thus, the queen stated that with the 12 marcas of silver requisitioned in the cathedral of Mondoñedo (1112), she would fight the counts who harmed the interests of the see itself, recently established in Villamayor de Val de Brea (Volens Valibriensem ecclessiam... deliberare de multis persecutionibus quae actenus per comites terrarum passa est; Ruiz, Irene. La reina doña Urraca...: 397-398 (doc. No. 27).

10. The Liber Testamentorum and the Libro de la Regla Colorada from Oviedo Cathedral both include versions of a document that annotated the enormous amount of money and precious metals that the famous Bishop Pelayo of Oviedo handed over to the queen in 1112, from the treasure of the see: 9280 metkales and 10400 solidos. On the other hand, doña Urraca granted him places, monasteries, lands and servile familias and, notably, the city of Oviedo itself in perpetuity, with its castle, land and jurisdiction, sicut ad regale ius pertinet. The specialists reject the last part, as well as the diplomatic formulae used (Ruiz, Irene. La reina doña Urraca...: 163-165). 
harnesses. These were in addition to sacred ornaments-crosses, chalices, plus some frontals or altar tables. ${ }^{11}$

What was the fate of these objects? In general, the details are limited to annotations about what the Queen seized and what it was valued at or weighed. That is why the data about two acts of pillage that the monastery of Valcabado suffered are significant. No acts are registered in the chancellery, but rather the circumstances that imply the decision to confiscate. In early 1115 , the Queen ordered Tello Fernández, her right-hand man in the area of Saldaña, to hand "la plata" (the silver) from the monastery (three goblets, a salt cellar and a cithara, maybe a small cauldron) over to "Pedro González" (perhaps Count Pedro González de Lara, the leading magnate on her side), and value it, then citing below the payment of the corresponding sum. At the end of the following year, the Queen ordered the same Tello Fernández to dismantle the monastery cross. This was a piece in silver that her aunt, Princess Elvira had ordered made. Nine marcas of silver were obtained; seven of these were handed over to one Pedro Peláez. Christians and Jews from the nearby town of Saldaña testified to both acts. ${ }^{12}$

As can be appreciated, decisions for the supply of resources were taken in the court and these were executed by territorial officials like Tello Fernández. When deciding or executing the decisions, it seems that not only chrematistic criteria were taken into account, nor did they seek to strip the house of all its treasures instantaneously. Thus, first the rich pieces of the tableware were taken. It was almost two years later when a liturgical cross that had been commissioned by women from the royal family itself was dismantled, in other words, this combined a double component of veneration and respect. The tasks of inspecting (like weighing and eventually dismantling the pieces) had to be entrusted to experts. The intervention of Hebreworigin goldsmiths is suggested by the notable role of local Jews in the reports, very

11. Gautier, Jean. "L"argent' dans l'Historia Compostellana. Un moment de l'histoire monetaire du León et de la Castille", Estudios en Homenaje a Don Claudio Sánchez Albornoz en sus 90 años [Anexos de Cuadernos de Historia de España]. Buenos Aires: Instituto de Historia de España, 1983: II, 423-452. The news that accompanies the requisition of the frontispiece of the main altar in Lugo Cathedral, dedicated to the Virgin Mary in 1112 is of special interest. The text requests her help to obtain and possess the kingdom peacefully; it also ponders the Marian relics kept in the see that work miracles and receive alms. In short, the requisition is valued at 100 silver marcas and it is assured that this is destined to paying the royal troops (ut reddam donativa militibus meis) (Ruiz, Irene. La reina doña Urraca...: 412-414, doc. No. 33).

12. I am indebted to Amancio Isla for an insightful comment. Although the second text seems to reflect that a large part of the silver was given to Pedro Peláez for a horse, it is possible that the seven marcas of silver remunerated his (indeterminate) services, and that Pedro Peláez handed over the horse as a roboratione, a traditional gesture of an offering; with it, the beneficiaries of a royal reward responded to the donation received. The roborationes (in Spanish robra) are also seen in private operations. They may be called ofertiones, and are conceptually similar to the notion of "contradón" or counter-gift. The two texts were written in notitia form, making use of a blank in fol. 3r of the so-called "Beato de Valcavado" (a copy of the well-known "Comentarios al Apocalipsis" by the Beato de Liébana, dated 970; it is in the Historical Library at the University of Valladolid). There are really four notitias, two of which are illegible; it is likely that all dealt with the same theme and were written at the same time. The editor interprets that their inclusion in a prestigious manuscript was full of symbolism, as they solemnised a future claim. (Ruiz, José Manuel. "El códice del Beato de Valcavado", Beato de Valcavado: Estudios. Valladolid: Secretariado de Publicaciones de la Universidad de Valladolid, 1993: II, 43-44). 
strange in the diplomatic customs except under exceptional circumstances, as in this case. In short, the events suggest that the sale or investment of the resources mentioned could have been immediate, and that the costs of war ate these up rapidly.

\section{War, exercise of disorder, destruction and plunder}

In the war situation of the reign of doña Urraca and the intense devastation it meant, the whole society was involved. The diplomas, chronicles and other versions coincide in this perception. In 1127, a certain diploma of Alfonso VII described the cruel and systematic havoc that had afflicted the king's property and men in León and the Tierra de Campos: it mentioned the murder and plundering of the Jews, the destruction of royal palaces, wine cellars and granaries, the burning of his forests and the emptying of the hunting grounds. It did not accuse isolated individuals or bands of outlaws of these crimes. The new king imposed a fine on all the homes in a wide area - the lands and alfoces between the rivers Cea and Carrión, the Way of Saint James and the Cantabrian Mountains. It also highlighted that the unrest had begun on the death of Alfonso VI, and had continued unabated until recent times. ${ }^{13}$

The Primer Anónimo from Sahagún Monastery describes something similar in the same scenario. ${ }^{14}$ Other similar data are known from various areas of the kingdom, with a particular incidence along the Way of Saint James. In western Castile, the fuero of Castrogeriz gave notice that, after Alfonso VI died, the people of the towns and the area attacked the Jews who lived in Castrillo, a hamlet in the alfoz, "matando a algunos, apresando a otros y saqueando a todos". ${ }^{15}$ Other witnesses evoke the general state of ruin of the rural environments. Among the most expressive is the

13. ...de malis que fecistis in iudaeos quos occidistis et accepistis suum avere, et in meos palazios quos destruxistis, et panem et vinum que inde accepistis et aurum et argentum et alia omnia multa, et meos montes quos comburastis et abscidistis et extinguistis venatu. Istas tres causas dimitto vobis et progenie vestra per secula. Et hoc feci pro amore Dei et remissione parentum meorum et pro diligentia quam habetis coram me. Et insuper accepi pecunias II ${ }^{o s}$ solidos de argento, de unaquaque casa istorum hominum quos supra diximus. Et ego sum pagadus a vobis, et vos liberi... (Colección Diplomática del Monasterio de Sahagún... : 111-112, doc. No. 1231).

14. [Los campesinos] levantáronse entonces a manera de bestias fieras... rompiendo e quebrantando los Palacios de los Reyes, las casas de los nobles, las Iglesias de los Obispos, e las Granjas, e obediencias de los abades; e otrosi gastando todas las cosas necesarias para el mantenimiento, matando los judios que fallavan... Escalona, Fray Romualdo de. Historia del Real Monasterio de San Benito de Sahagún, Madrid, 1782, Apéndice Primero, Primer Anónimo: 305 (from no won: Primer Anónimo de Sahagún). The similarity between the two texts is intriguing. On the other hand, this should be evaluated as a 'mole', understanding his sentence by the ecclesiastics (and its possible exaggeration), as a resort to emphasise "the dangers of the subversion of order" (Pallares, Maria del Carmen; Portela, Ermelindo. La reina Urraca...: 152).

15. "Killing some, taking others hostage and robbing all"... Et levaverunt se barones de Castro cum tota sua alfoz ad illa morte de rege Aldefonso super illos iudeos de Castriello, et ex illis occiderunt et ex illis captivaverunt, et totos illos predaverunt..." (Martínez, Gonzalo. Los fueros de Castrogeriz. Burgos: Rico Adrados, 2010: 54). In line with other information from the same fuero, around 1035, there was a first pogrom in which some seventy Jews from the town died; the others were forced to move to Castrillo, where a second massacre took place. The village is still known as "Castrillo de Matajudíos". Queen Urraca and her husband, Alfonso el 
inventory of disasters that appears in the preamble of the fuero of Oca. The discord between Queen Urraca and Alfonso el Batallador had turned into great clashes between their supporters in the lands of eastern Castile. Both sides took hostages and demanded huge ransoms. Both sides had converted cities and castles into lairs from which to sack the surroundings, desecrating holy places and stealing grain, wine and livestock; they also took the inhabitants prisoner, demanding enormous ransoms for their freedom, among other acts. They were, the text states, "como sarracenos y cananeos", "como herejes y cismáticos". There was so much desolation that it was only possible to live in caves, or under the paradoxical shelter of cities and castles. ${ }^{16}$

Other images detail how the violence of the war activated the circulation of wealth -although in a different way from the requisition of Queen Urraca. The testimonials and their actors are found from the Castilian frontier to the heart of Galicia. The nobles, backed by the peasants, were the protagonists of one of the episodes that the Historia compostelana reflects on. This is the "treason" by Arias Pérez and other Galician lords to the archbishop Diego Gelmírez and the Count Pedro Froilaz, Infante Alfonso Raimúndez's champions. The conspirators seized the Count's wife, who was the prince's nanny, and the Infante himself, mistreating his knights. The "traitors" and the "brotherhood" that framed the people of the country later attacked the prelate's camp. They stole his trousseau and sacred medals, which they broke up to share out. The chronicler refers to them adorning their belts and the hems of their vestments with the cloth from the bishop's chasuble; they also dismantled the golden chalice that was kept in the prelate's portable chapel, his silver altar and a crucifix of extraordinary value. ${ }^{17}$ The harnesses and equipment of

Batallador, tried to prevent new massacres; from then on, anyone who killed a Jew in Castrogeriz would suffer the same punishment as for the death of a Christian.

16. "like Saracens and Canaanites" "like heretics and schismatics" This fuero, conserved among the papers in the monastery of San Juan de la Peña, has been dated from the mid $12^{\text {th }}$ century. It begins with a profoundly dramatic report on the origins of the town of Villafranca Montes de Oca: Audite de temporibus quando mortuus est rex Ildefonsus imperator tocius Spanie... Et prendit unus a destris et alter a sinistris cum hostes suas, et preliabuntur inter se usque ad mortem. Et captivabunt se alter ad alteri sicut sarrazini et canaeni. Et mittunt se in graves presones et in ferros magnos et innumerabiles tormentas in fame et siti et nuditate, usque se reddemissent quantum possunt dare aut promittere. Et exeunt de civitatibus aut de castellis et predabunt omnia terra, monasteriis violabunt, ecclesiis et omnia ornamenta qui ad Deum pertinet extrahunt de eas sicut aeritici et scimatici, sine ulla misericordia. Et predabunt universa terra panem et vinum et omnia indumenta et animalia, iumenta et peccora, et omnes homines ducebant captivos et mittebant illis in tortoribus atque cruationibus ut se reddemisent, quod non habebant. Et erat tantum desolata hec terra, ita ut non possunt omnes habitare in ea, si non est in civitate aut in castello vel in spelunca aut in cavernis terrae... (Lacarra, José María, ed. "Dos documentos interesantes para la historia de Portugal", Colonización, parias, repoblación y otros estudios. Saragossa: Anubar, 1981: 222).

17. ...non solum omnia presulis suppellectilia abstulerunt, verum etiam, quod humanis auribus terribile insonat, in eius capellam suas manus sacrilegas iniecerunt: eius namque infulam iuxta insaciatam luporum rapacitatem inter se frustatim diripientes suis pravis usibus profuturam conservari non horruerunt; ex qua nimirum infula suarum vestium horas et limbos quasi decorando sine ulla mora temporis dedecorarunt. Aureum quoque vasculum, quo Dominicum corpus, nostra scilicet hostia salutaris, immolatur, timembri divisione partientes ille inferiorem partem, iste vero superiorem, hic autem reliquam parte sibi exsecrabilius vendicare procul procul dubio non formidarunt. Aram denique argenteam et crucifixum mirifica aurificis manu consculptum nulla dissimili ratione partiti sunt... (Historia Compostellana...: 93). 
the fear-stricken episcopal host suffered the same fate. The understanding between nobles and peasants to carry out these outrages the chroniclers denounced must not have been rare in those times. ${ }^{18}$

The case of one by the name of Sancho, servant of a neighbour from Estella, illustrates a different perspective: that of a modest combatant who served as a footsoldier or knight on one of Alfonso el Batallador's military expeditions to Castile. The king having ordered that each household had to contribute one man for the war, the burgher Pedro Engelberti, who spent his later years as a monk in the Cluniac priory of Santa María de Nájera, sent him as his contribution. During the expedition, there was no lack of opportunities to rob. In particular, Sancho and his companions sacked a certain church, from which they took various liturgical vestments. It seems that he had these with him when he returned to Navarre shortly after. He died with this guilt and, according to what Peter the Venerable wrote, his old owner was a witness to his unearthly penance. ${ }^{19}$

The role of the urban populations in the war offers a new point of view. The chroniclers echo how the people of the towns and cities participated in the campaigns of Alfonso el Batallador. Contingents from Nájera and Carrión, León, Burgos, as well as Zamora, Palencia and Sahagún took part in the siege of Astorga. ${ }^{20}$ The news concerns particularly "Frankish" burghers from Sahagún, the main antagonists of the monastery of Sahagún throughout the Primer Anónimo. Its author portrayed them as accomplices, even instigators of the brutality of the Aragonese king, his brother the "false monk" Ramiro and his knights. In fact, he argued, there were

18. The chronicle of the monastery of Sahagún highlights the collusion between the rebellious peasants in the district (who also organised themselves as a "brotherhood"), and those nobles who show a willingness to be their defenders:...En este tiempo todos los rústicos labradores, é menuda gente se ayuntaron, faciendo conjuración contra sus señores, que ninguno de ellos diese a sus señores servicio debido. E a esta conjuración llamaban hermandad... e si alguno de los Nobles les diese favor e ayuda, á tal como este deseaban que fuese su Rey, y Señor... (Escalona, Romualdo de. Historia del Real Monasterio de San Benito de Sahagún...: 305).

19. In 1141, the famous abbot Peter the Venerable travelled to Spain to negotiate with Alfonso VII for the restoration of the census of 500/1000 gold coins that his ancestors Ferdinand I and Alfonso VI had paid to the monastery of Cluny in other times. On passing the priory of Nájera, he heard from Pedro Engelberti himself the tale of a prodigious vision. The spectre of the servant, who had died shortly after his return from the war, had once appeared to him. He commissioned him to pay off certain debts he had left on dying; at the same time, he explained that he was part of "an army" of sorrowful souls that came to Castile to compensate for the crimes they had committed during the campaigns of Alfonso el Batallador. He also explained that the Aragonese king had spent a long time in Purgatory, before being freed "by the prayers of the Cluniac monks" (Petrus Venerabilis, De Miraculis. Mâcon, Bibliotheca Cluniacensis, 1915: 1293-1296; Lacarra, José María. “Una aparición de ultratumba en Estella”. Príncipe de Viana, 14 (1944): 173-184).

20. Historia Compostellana: 113-114; it contrasts the identification of the Battler's troops by their towns and cities of origin with the queen's army, more territorial (Galicia and the Tierra de Campos are mentioned, plus Castilians and Asturians). About the importance of the emigration of "francos" to the western part of the Peninsula, their otherness and their dynamic role in urban environments, Martínez, Pascual. "Los francos en la España de los siglos XI y XII", Los fueros de Avilés y su época, Juan Ignacio Ruiz de la Peña, Maria Josefa Sanz, Miguel Calleja, coords. Oviedo: Real Instituto de Estudios Asturianos, 2012: 253-280. 
no good "Frankish" burghers, not even the clergy, as greed that did not stop before sacrilege or murder prevailed in all of them. ${ }^{21}$

Various accounts in this work reiterate or detail what is referred to above. Thus, there is information that details the accounts in the preamble of the fuero of Oca or the Historia Compostelana about the captives and extortion that had accompanied the factional fighting and raids. It speaks harshly of how the burghers preyed on "nobles and knights" or "middling and rich" of the surroundings. The aim was to obtain large ransoms. The prisoners were subjected to torture of all kinds to break their will, and those who could sought hostages to take their place. It also describes the rise of a market for the resale of captives. Their price varied according to what each could offer to buy his or her own freedom and the competition between their captors to obtain "mayor ganancia de ellos". ${ }^{22}$

The abbot de Sahagún appears as a victim of a similar assault to the one suffered by Bishop Gelmírez in the Historia Compostelana. During a tour of his priories or "obediencias", Abbot Domingo had arrived in San Pedro de las Dueñas, the nearby monastery that was the female subsidiary of Sahagún. Burghers from the town and Aragonese knights surprised the party there and stripped them of all they had. ${ }^{23}$ San Pedro de las Dueñas suffered other attacks. In one of these, burghers burst into the monastery, "y robaron todo aquello que sus manos hallaron", among other things, the amounts placed in protection there by members of the nobility. ${ }^{24}$ This shows that the monastery was unable to protect the wealth of the high-ranking people. According to the Historia Compostelana, neither the churches of Extremadura nor those of Tierra de Campos were able to protect what the common people deposited in them, in the vain hope that their sacredness would preserve this from plunder.

The testimonies coincide: Urraca's reign was a time of war, and in that time, the circulation of wealth acquired peculiar features, among which the ongoing generalised confiscation stands out. Monarchs and knights, burghers and peasants, Christians and Jews - all participated in the vicissitudes of a time with an air of a bloody feast, even switching roles depending on the circumstances.

It is clear, moreover, that the seizures did not only affect precious objects. The confiscation of land destined for the needs of war was regularly sandwiched between

21. Escalona, Romualdo de. Historia del Real Monasterio de San Benito de Sahagún...: 313 and 320.

22. "greater profit from them" Escalona, Romualdo de. Historia del Real Monasterio de San Benito de Sahagún...: 322-324. The abuse could end up with the death of the prisoner, as narrated about a certain burgher, in whose house were found the remains of several people who had assassinated: era por cierto aquel eunuco del cuento e numero de aquellos que acostumbraban comprar los captivos, e dándoles graves tormentos demandábanles siete tanto de aquello que habian dado (Escalona, Romualdo de. Historia del Real Monasterio de San Benito de Sahagún...: 345).

23. ...Luego los echaron por tierra, las arcas e todo lo que llevábamos todo lo tomaron, y despojaron a los hombres, including the chapel the abbot carried (Escalona, Romualdo de. Historia del Real Monasterio de San Benito de Sahagún...: 322).

24. "and stole everything their hands found there": Escalona, Romualdo de. Historia del Real Monasterio de San Benito de Sahagún...: 331. 
operations. Undoubtedly, income from the land covered part of the funding of the war, paying the salaries of the fighters. ${ }^{25}$

\section{The army on the march: The campaign against Alfonso el Batallador (1127)}

Peter, archdeacon of Barcelona Cathedral, spent a good part of the summer of 1127 in the lands on the Douro. He had been sent by his lord, Ramón Berenguer III, Count of Barcelona and Besalú, $d u x$ and Marquis of Provence, to receive on his behalf a solemn oath from Alfonso VII and his magnates. As part of the negotiations for the marriage of the splendid king of León and Castile to his daughter Berengaria, the count demanded guarantees that the union would be blessed canonically, and that the king would never leave his wife.

There is a document in the Archive of the Crown of Aragon that explains the commitment through a series of ceremonies similar to Alfonso VII's oath to his future father-in-law. ${ }^{26}$ On each occasion, the place, the day and names of the delegates are detailed. The ceremonies stretched from the $23^{\text {rd }}$ of June to the $25^{\text {th }}$ of July. On the former date, the archdeacon received the monarch's oath in Sahagún Monastery, seconded by one of his nobles. Six days later, on the $29^{\text {th }}$ of June, the monastery of San Zoilo of Carrión was the scenario of the second. On the $2^{\text {nd }}$ of July, the archdeacon was in Frómista, whose church of San Martín hosted the third. On the $4^{\text {th }}$ of July, the fourth took place in Palenzuela (Palencie comitis in the text). On the $9^{\text {th }}$ and $25^{\text {th }}$ of the same month, the archdeacon requested the last commitments in two churches in Burgos. His commentators have estimated that the alliance between Barcelona and León, assured with the marriage of Alfonso and Berenguela in the autumn of 1128, involved the wish to neutralize King Alfonso el Batallador. ${ }^{27}$

\footnotetext{
25. In early April 1127, Alfonso VII returned the Sahagún Monastery to the Priory of San Salvador de Nogal de las Huertas, close to the town of Carrión. Remembering the difficulties that he faced to obtain the kingdom, the monarch explained that he had requisitioned it to use its property and incomes to pay his knights. (multis pro captando regno neccesitatibus... meis illud militibus dedi; Colección Diplomática del Monasterio de Sahagún (857-1230). IV (1110-1199), 110-111, doc. No. 1230).

26. Archivo de la Corona de Aragón, Real Cancillería, pergaminos de Ramón Berenguer III, s/f, doc. No. 28. The formula used consisted of an oath to the count (Iuro ego [X, Y, Z...] tibi Raimundo Barchinonensis et Bisuldunensis comiti et Provincie duci ac marchioni) in which the marriage of the sovereign to Berenguela was guaranteed cum benediccione ecclesiastica et... eam ullo modo non dimittat per Deum et hec [sanctam scripturam].

27. Aurell, Martin. Les noces du comte. Mariage et pouvoir en Catalogne (785-1213). Paris: Publications de la Sorbonne, 1995: 373-374. Reilly, Bernard F. The Kingdom of León-Castilla Under King Alfonso VII 11261157. Philadelphia: University of Pennsylvania Press, 1998: 19-20. Reilly has considered it evidence of the young king's haste to marry and ensure his still-unstable political position, underlining the text's peculiarities and diplomatic shortcomings. While Aurell suggests that it is an original ("Ramón Berenguer III's emissary had returned to Barcelona with the document attesting to his promise", Aurell, Martin. Les noces $d u$ comte...: 373), Reilly considers that the document, "written in Carolingian script on an irregular piece of parchment", is "a $13^{\text {th }}$-century copy which is extracted from a longer, more formal account by
} 
However, the document is open to other readings. The names of the participants, the ritual elements it contains, or the sequence of the acts, offer quite a lot of information about who the men of the moment probably were, the ways of underlining the sacred nature of the agreement, or about the meaning of territorial.

To begin with, the scenarios draw our attention. It is clear that the ceremonies were concentrated on a certain stretch of the Way of Saint James as it crosses the Meseta. Indeed, the towns of Sahagún, Carrión and Frómista, plus the city of Burgos, were in a line on the corridor, summarised shortly after in the "Pilgrim's Guide" ${ }^{28}$ Two clarifications are necessary: it is clear that the archdeacon was travelling in the opposite direction to the pilgrimage, as if he were coming from Santiago de Compostela, and that he left the route momentarily after Frómista, deviating a few kilometres south to stop in Palenzuela; in the final weeks of his mission, he remained in the Castilian capital, once again on the Way. The order of the stages simply certifies the importance of the Way as a backbone of the kingdom in that epoch. As well as a route for pilgrimage, as the mentioned guide emphasises, the Jacobean corridor was the main communication route in the Hispanic north, "the great route" that al-Idrîsî described around the same time. ${ }^{29}$ The towns and cities that festooned it were thus a rosary of strategic points for trade, control of the land or war, as well as for piety.

From this perspective, the Chronica Adefonsi Imperatoris offers parallel evidence about the delicate situation of the time in the west of the Peninsula. King Alfonso el Batallador had entered Castile in summer 1127 to reinforce Nájera, Castrogeriz and many other castles he possessed in the surroundings. On hearing the news, Alfonso VII sent emissaries to Galicia and Asturias, León and Castile to raise troops. A large army gathered, and set off to meet the Aragonese, who they sighted in Vallis Tamari. The place, between Castrogeriz and Hornillos del Camino, must correspond to the area around the modern Tamarón. A century before, there had been a battle where Ferdinand I of Castile defeated and killed King Vermudo III of León. However, this time no fighting took place. The Chronica sustains that being aware of his difficult position and that he could not withdraw without the risk of being harassed, the Battler sent envoys to Alfonso VII. In his proposal he promised to return to his homeland in less than forty days and not to deviate from the via on the entire route. Alfonso VII accepted this, pressured by his advisers. ${ }^{30}$

Considering these circumstances, it is clear that the Catalan clergyman accompanied the royal army on its march to the east. The places mentioned indicate

a scribe who was not too familiar with the older text of the original" (Reilly, Bernard F. The Kingdom of León-Castilla...: 19, doc. No. 15).

28. Liber Sancti Iacobi. Codex Calixtinus, eds. Klaus Herbers, Manuel Santos. La Coruña: Xunta de Galicia, 1998: 236, liber V, capitulum III [de nominibus villarum itineris Sancti Iacobi]....inde urbs Burgas [Burgos], inde Alterdallia [Tardajos], inde Furnellos [Hornillos], inde Castra Sorecia [Castrogeriz], inde pons Fiterie [el puente de Hitero], inde Frumesta [Frómista], inde Karrionus [Carrión de los Condes], que est villa abilis et obtima, pane et vino et carne et omni fertilitate felix, inde est Sanctus Facundus [Sahagún], omnibus felicitatibus affluens... 29. Idrîsî. La prémière géographie de l'Occident, eds. Henri Bresc, Annliese Nef, Paris: Flammarion, 1999: 41. 30. Chronica Adefonsi Imperatoris, [Chronica Hispana Saeculi XII. Pars I], eds. Emma Falque, Juan Gil, Antonio Maya. Turnhout: Brepols, 1990: 154-155. This via is the Way of Saint James. 
the stages it followed and justify a significant omission: under normal circumstances, the archdeacon would have gone from Frómista to Burgos passing through Castrogeriz, without leaving the Way. His deviation to the south is a reminder that the circumstances in 1127 were exceptional. Castrogeriz was one of the places that had been in Aragonese hands for some time; as mentioned above, its garrison did not leave until 1131.

The dates and locations of the oaths suggest other reflections. On the $23^{\text {rd }}$ of June, eve of the feast of Saint John the Baptist, the first of the ceremonies was held on the altar dedicated to the Holy Precursor in the monastery in Sahagún. Certainly, such a precise conjunction of time and space served to reinforce the sacredness of the act, integrating it into the characteristics of one of the great feasts of the liturgical calendar. Regarding the $29^{\text {th }}$ of June, the scenario of the ceremony was the altar of the Virgin Mary in San Zoilo of Carrión. In this case, the text itself names the feast day, not the date of the month (die festo Sancti Petri), which underlines the charisma of the ceremony: the commemoration of Saint Peter, of particular importance in the order of Cluny as the co-patron of the house. The commemoration of Saint Peter also impregnates the immediate swearing of the oath on the altar of San Martín of Frómista (sabbato post festum Sancti Petri). It must be added that this other monastery depended on San Zoilo of Carrión, and its founding in the mid $11^{\text {th }}$ century by the Countess-Queen Mayor, Ferdinand I's mother, linked it closely to the royal family; Queen Urraca had renounced its ownership as recently as $1118 .^{31}$

With regard to Palenzuela, the celebration before the altar of Saint Eulalia recalls that this teenage martyr was the patron saint of the city of Barcelona and co-holder of the cathedral, where her relics were worshiped. It is appropriate to emphasize the symbolism of a ceremony officiated by a dignitary from the seat of the Holy Cross and Saint Eulalia as a representative of the lord of the saint's city and before an altar where her relics were also kept. ${ }^{32}$ In short, the ceremony of the oath on the altar of

\footnotetext{
31. Reformed by Alfonso VI, Sahagún was the home of the tomb of this monarch, Alfonso VII's grandfather and the model for his restorative policy —as its black monks were careful to point out. The customs of Cluny were followed in this monastery but it was not part of the Cluniacensis Ecclesia, in contrast with San Zoilo and San Martín in Frómista. After 1173, San Zoilo became a stable seat of the Camerarius of Cluny in Spain -in other words, of the abbot's representative, its prior assimilating this condition. Yet, the house must have been the residence of some previous steward, and perhaps the prior Esteban held both posts around 1127 (Reglero, Carlos Manuel. Cluny en España. Los prioratos de la provincia y sus redes sociales (1073-ca. 1270). Leon: Centro de Estudios e Investigación "San Isidoro", $2008: 608$ and following). About the problems of the founding and architecture of the latter famous monastery, see Senra, José Luis. “Origen, muerte y resurrección de la iglesia de San Martín de Frómista”, Frómista 10661904. San Martín, centenario de una restauración, Javier Ribera, coord. Valladolid: Fundación del Patrimonio Histórico de Castilla y León, 2004: 19-37.

32. Parallel traditions propose that there were two saints with the same name who suffered similar martyrdoms in the times of the Emperor Diocletian, one in Mérida and the other in Barcelona. Various explanations have been sought for such a rare coincidence. The most likely does not question the antiquity of the cult of the Mérida saint and suggests that "the presence of a relic [of hers in Barcelona] led to the duplication of the saints"; there is a lack of strong evidence to believe that this incident occurred before the $8^{\text {th }}$ century, the inventio of the Barcelona relics and their transfer to the cathedral being dated from 877 (García, Carmen. El culto de los santos en la España romana y visigoda. Madrid: Consejo Superior de Investigaciones Científicas, 1966: 284-303; quote on page 288). The transfer and worship
} 
Santiago of Burgos was held on the same day as the apostle's feast, which indicates that the keys described above were used rather systematically. This time, it is again fitting to highlight the diverse and complex links of the worship and the house of the Hijo del Trueno (Son of Thunder) with the Leonese monarchy. ${ }^{33}$

The personality of the noble guarantors of the commitment reveals another key to the situation ${ }^{34}$ In Sahagún, Rodrigo Martínez, princeps Legionis was next to the king. Rodrigo Martínez could trace his lineage back to at least the early days of King Ramiro II of León, two centuries before. His father, Count Martín Flaínez, had been the most important of the Leonese lords from the beginning of the 1090s until his death in 1108 at the massacre of Uclés.

Four magnates coincided in the monastery of San Zoilo. These were Pedro López, the tenente of the town of Carrión; Ladrón, from Álava, who had become a vassal of Alfonso VII; Count Suero Vermúdez, lord of western Asturias, and Ramiro Froilaz. Count Suero had cemented his personal success on unwavering loyalty to Queen Urraca, after whose death he moved into service to his son. Ramiro Froilaz, in contrast, was another member of the same kin as Rodrigo Martínez; his father, Count Froila Díaz, became comes legionensium after the death of Martín Flaínez, remaining by the Queen's side until his demise in 1119.

Instead, in Frómista, only the count Peter of Lara swore the oath, in other words, Pedro González de Lara, never welcomed by Urraca's son and heir. ${ }^{35}$ Two other magnates swore the oath in Palenzuela: Lope Díaz "de Alava" —commonly identified by his sobriquet "de Haro" and his title as Count of Vizcaya-, and García Garcés de Nájera, son of another of those who fell at Uclés, Count García Ordóñez.

of relics of the Mérida Eulalia in the lands in the north-west could have been posterior to the Islamic conquest (as occurred in other cases). In short, a different scenario to the passion of the martyr could be recreated -duplicating her personality. On the other hand, the spread of the cult of Saint Eulalia in Castile and León could somehow depend on the religious climate in the north-east of Spain: The Catalan clergy, particularly in Oviedo and Palencia in the $11^{\text {th }}$ century, together with their influx in the implantation of some other cult, especially that of Saint Antoninus, must be borne in mind (Martínez, Gonzalo. La sede episcopal de Palencia hasta 1085. Palencia: Asociación de Amigos de la Catedral, 1994). Anyway, it is probable that the archdeacon and those attending the ceremony accepted the two alleged martyrs without any great problems.

33. Herbers, Klaus. Política y veneración de santos en la Península Ibérica. Desarrollo del "Santiago político". Pontevedra: Fundación Cultural de Amigos del Románico, 2006: 43-55; the author considers the reign of Alfonso VII crucial.

34. An overview of the nobility in this period, accompanied by a useful prosopography of the counts, in Barton, Simon. The aristocracy in twelfth-century León and Castile. Cambridge: Cambridge University Press, 1997. Various of the nobles cited in the text have merited recent monographs. For Suero Vermúdez: Calleja, Miguel. El conde Suero Vermúdez, su parentela y su entorno social. La aristocracia asturleonesa en los siglos XI y XII. Oviedo: KRK ediciones, 2001. About Pedro and Rodrigo González de Lara: Sánchez, Antonio. Los Lara. Un linaje castellano de la plena Edad Media. Burgos: Diputación de Burgos, 2007: 29-47. Regarding Rodrigo Martínez and his distant cousin, Ramiro Froilaz: Martínez, Pascual. "Los espacios de poder de la nobleza leonesa en el siglo XII", La pervivencia del concepto. Nuevas reflexiones sobre la ordenación social del espacio en la Edad Media, José Ángel Sesma, Carlos Laliena, coords. Saragossa: Universidad de Zaragoza, 2008: 219-257.

35. In the same line, Chronica Adefonsi Imperatoris, a model of palace chronicle, does not hesitate to repeatedly denounce his connivance with the Aragonese sovereign; this time, it holds him responsible for preventing Alfonso VII from launching a decisive attack on his enemy. 
There were two successive ceremonies in Burgos, as mentioned above. The one before the altar of Saint Stephen was carried out by Count Rodrigo "de las Asturias" (Rodrigo González, brother of the Lord of Lara), who dominated the "Asturias de Santillana", and Count Bertrán de Risnel, one of the Frankish nobles who entered Castile with Alfonso el Batallador. ${ }^{36}$ Finally, the oath sworn on the Altar of Santiago was attended by Rodrigo Gómez. He was from the house of Salvadórez, lords of the Bureba, and his father had been Count Gómez González, who died in Queen Urraca's service.

The areas dominated by ones or the others covered a wide space, from the Cantabrian sea to the Douro, and from the Bierzo to the Ebro and the Iberian mountains. Although it contains no mention of nobles from Galicia, the document is a very significant register. A certain dynamic is evidenced from these data. On the one hand, the guarantees that the count of Barcelona had demanded were given in stages, as the great lords with their retinues joined the royal army advancing along the Way of Saint James to meet Alfonso el Batallador (or even in Burgos, with the campaign completed with advantage for Alfonso VII). On the other hand, the calendar of the festivities, and the monasteries, churches and altars with the relics of their namesakes, were carefully interwoven. With this, the sacred, memorial and propitiatory sense of a repetition of political acts was emphasised. A certain calculation can be perceived in the liturgy and power that surrounded these: the strengthening of the ties between the monarch, the warlords and the army to ensure military success.

\section{The losers of 1130}

The Chronica Adefonsi Imperatoris supplies much other news about the prolongation of the instability and war after the death of doña Urraca in March 1126. Recently these have been integrated into a wide perspective that describes the fate of the defeated parties in the Spain of the High and Late Middle Ages. ${ }^{37}$

The pages of this chronicle contain various actors, always nobles, and varied formulae for resolving conflicts. The necessary capture, timely mercy and rigorous imprisonment were useful instruments for dismantling revolts. Humiliation and the loss of goods and honours published the sometimes-definitive failure of the rebellious. The recognition of guilt could temper the king's wrath, according to the chronicler. In the opposite sense, guilty acts came to lead to infamy for the whole

\footnotetext{
36. Bertrán de Risnel had become Count Pedro González de Lara's son-in-law. Now, after Burgos had been recovered by Alfonso VII, he remained as lord of the city; the ambiguous position of his new relatives must be borne in mind.

37. Alvira, Martín. "Rebeldes y herejes vencidos en las fuentes cronísticas hispanas (siglos XI-XIII)", El cuerpo derrotados: cómo trataban musulmanes y cristianos a los enemigos vencidos (Península Ibérica, ss. VIII-XIII), Maribel Fierro, Francisco García Fitz, coords. Madrid: Consejo Superior de Investigaciones Científicas, 2008: 213-223.
} 
family. Moreover, this further alienated the rebels from the executors of royal policy (who were always other nobles).

Most of those mentioned had been relevant figures in the court of Queen Urraca, a possible indication that the process of succession was far from meeting the expectations of many of her loyal supporters. This was the case of the Castilian counts Pedro and Rodrigo González de Lara, or the Asturian magnates Gonzalo Peláez and Pedro Díaz. They all rebelled against her successor, Alfonso VII, in the first years of his rule. The truth is that the young monarch placed his cause in the hands of some of his mother's other old servants, like the counts Suero Vermúdez and Rodrigo Martínez.

The chronicle does not dwell on the reasons of rebels and loyalists, beyond denouncing that some had betrayed a commitment of allegiance to the monarch that the others maintained, and perceiving certain connivance of some with Alfonso el Batallador (a useful illustration of changes of allegiance). ${ }^{38}$ After all, an exemplary story like this need not be very analytical. However, some of its descriptions go beyond the episodic.

The rebellion of Pedro Díaz is of special interest for the case. In 1130, this former champion of the Queen was strong in Valle, an oppidum situated a day's ride from León. ${ }^{39}$ It seems that he was followed by a considerable number of knights and commoners, who perhaps formed an armed retinue of clients or non-noble vassals. The king entrusted the task of reducing it to Count Rodrigo Martínez, together with his brother, Osorio. As he failed to obtain results, the monarch had to go there in person. He ordered his ministros, a body of experts, to build siege machines. Given their destructive effects, the fortress had to surrender. ${ }^{40}$

\footnotetext{
38. Escalona, Julio. “Misericordia regia, es decir, negociemos. Alfonso VII y los Lara en la Chronica Adefonsi Imperatoris", Lucha política. Condena y legitimación en la España medieval, Isabel Alfonso, Julio Escalona, Georges Martin, coords. Lyon: ENS Éditions, 2004: 101-152.

39. The name corresponds to the village of Valle de Mansilla. There are still imprints there of two fortified areas with earthworks, El Castro and La Torre Vieja. The first is an ancient complex situated on the heights of the terraces of the Esla. It is estimated that it was reoccupied in the $10^{\text {th }}$ century. However, over the following century, a process of the habitat sliding down to the lower valle, its current location, took place. At the same time, the second of the fortified areas must have been conditioned, a short distance from the former. The latter is smaller and has a certain aspect of a hillock (a moat and a perimetral slope elevate it). The latter has been identified as the oppidum de Valle of the chronicle (Gutiérrez, José Avelino. Fortificaciones y feudalismo en el origen y formación del reino leonés (siglos IX-XIII), Valladolid: Universidad de Valladolid, 1995: 318-321). It appears that Pedro Díaz had been tenente of the pace during the 1120s (Colección Documental del Monasterio de San Pedro de Eslonza. I (912-1300), eds. José Manuel Ruiz, Irene Ruiz. Leon: Centro de Estudios e Investigación “San Isidoro", 2007: 1120 (doc. No. 81) and 207-209 (doc. No. 83, 1126); given what is read in this latter diploma, he may also have held the post of tenente of Toledo and the illas torres in León). The author annotated a later indication in the castellum que fuit de Petro Didaz, 321 (doc. No. 151; it's dated in 1179).

40. Chronica Adefonsi Imperatoris...: 159-160: Precepit rex Legionis comiti Roderico Martini et fratri suo Osorio ut uenirent in terram Legionis et obsiderent Petrum Didaci, qui erat rebellis in oppido Valle cum magna turba militum et peditum. Et uenerunt et obsederunt illud castellum. Sed qui intus erant dicebant multam blasphemiam comiti Roderico et fratri suo et comes non poterat firmiter debellare eos. Hoc audito rex festinus uenit et iussit ministris suis facere uineas et machinas et multa ingenia circa muros castelli. Et illi, qui cum rege erant, mittebant super ipsos, qui intus erant, multas sagittas et petras et dirupti sunt muri eius in circuitu. At Petrus Didaci, cum uideret se nimium
} 
Then a striking event took place: Pedro Díaz requested to be put under the king's custody. He feared Rodrigo Martínez, from whom he expected no mercy. It should be noted that the order to attack the rebels was given by the tenente of Las Torres in León, the most important and closest royal castle. This post had previously been in the hands of Pedro Díaz himself, which may suggest an unfriendly takeover. In addition, Pedro Diaz's co-adventurers, perhaps the same ones that had been in his service in Leon, had mocked the count's useless attacks.

Indeed, Pedro Díaz managed to avoid the count's revenge. However, the chronicler estimates that he lost all possibility of obtaining any benefit from Alfonso VII (nor anyone else), and died in misery. ${ }^{41}$ Meanwhile, his men were left at the mercy of Rodrigo Martínez. What is interesting about this part of the text is that it shows examples of how the losers were treated. The first mention is for those who were placed in prison to force them to hand over all their belongings. Then, those who remained were obliged to render service as knights, but for free and for an unlimited time. The last group was made up of those accused of insulting the count. They were dispossessed like the former, but moreover they suffered a defamatory situation, parallel to the grievances they had caused: they were treated like draft animals. The count "los hizo uncir con bueyes, y arar y pacer hierbas, y beber agua de las charcas, y comer paja en el pesebre" (had them yoked like oxen and plough and graze grasses, and drink water from puddles, and eat straw in the manger). In other words, they were forced to do work that was in the antipodes of their "military" condition, and even beyond the service of "human" work that many peasants rendered periodically to their lords under the name of sernas, operas or geras; it is difficult to decide if this was merely a symbolic representation, or if this

oppressum, cepit clamare et dicere regi: "Domine mi rex, ego sum reus in te et culpabilis. Deprecor te per Deum, qui te in omnibus adiubat, ne dimittas me nec uxorem meam nec filios meos in manus comitis Roderici, sed tu accipe de me tuam uindictam secundum tuam misericordiam". Hoc audita, rex, sicut solitus erat, misericordia motus est et fecit eum uenire ad se et Pelagium Froyle, qui erat cum eo, et misit eos in tentoria sua. Post paucos uero dies iussit eos liberos abire. Sed Petrus Didaci huc et illuc sine rege et benefactore deuenit in magna egritudine et mortuus est pauper et miser.

41. The reasoning is based on a recognised data: the personal success of the nobles depended to a good extent on the royal mercedes and honores (or more in general, of generous benefactores). This was influenced by the successor customs of the nobility; their cognate practices fragmented their legacy with each generational change (Martínez, Pascual. "Reyes y nobles en León (ca. 860-1160)", Monarquía y sociedad en el reino de León de Alfonso III a Alfonso VII, José María Fernández, coord. León: Centro de Estudios e Investigación San Isidoro 2007: I, 149-200. Other sources and the Chronica Adefonsi Imperatoris itself qualify the fate of Pedro Díaz's kin. The magnate had requested the king to extend his protection to his wife and chidren, in other words, to María Ordoñez and the nine offspring from their marriage. Pedro Díaz lived until the mid 1130s, and his descendants recomposed the family status. What we know leads us to reflect on this. One of his daughters, Guntrodo, had concubinal relations with Alfonso VII, from which the Princess-Queen Urraca la Asturiana was born. Her father, the king, betrothed her to his ally King García Ramírez of Pamplona; after being widowed, she became the Lady of Asturias — maintaining the title of "queen". Two of Pedro Díaz's other sons, Diego Pérez Abregón and Gonzalo Pérez Gembelín, were among the most important nobles in this region; the former began the powerful lineage of Álvarez de las Asturias. Perhaps the price of royal mercy was to hand over one of the maidens of the defeated kin, which ultimately helped him to recuperate a certain protagonism (Torres Sevilla-Quiñones de León, Margarita. Linajes nobiliarios de León y Castilla (Siglos IX-XIII). Valladolid: Junta de Castilla y León, Consejería de Educación y Cultura 1999: 374-394). 


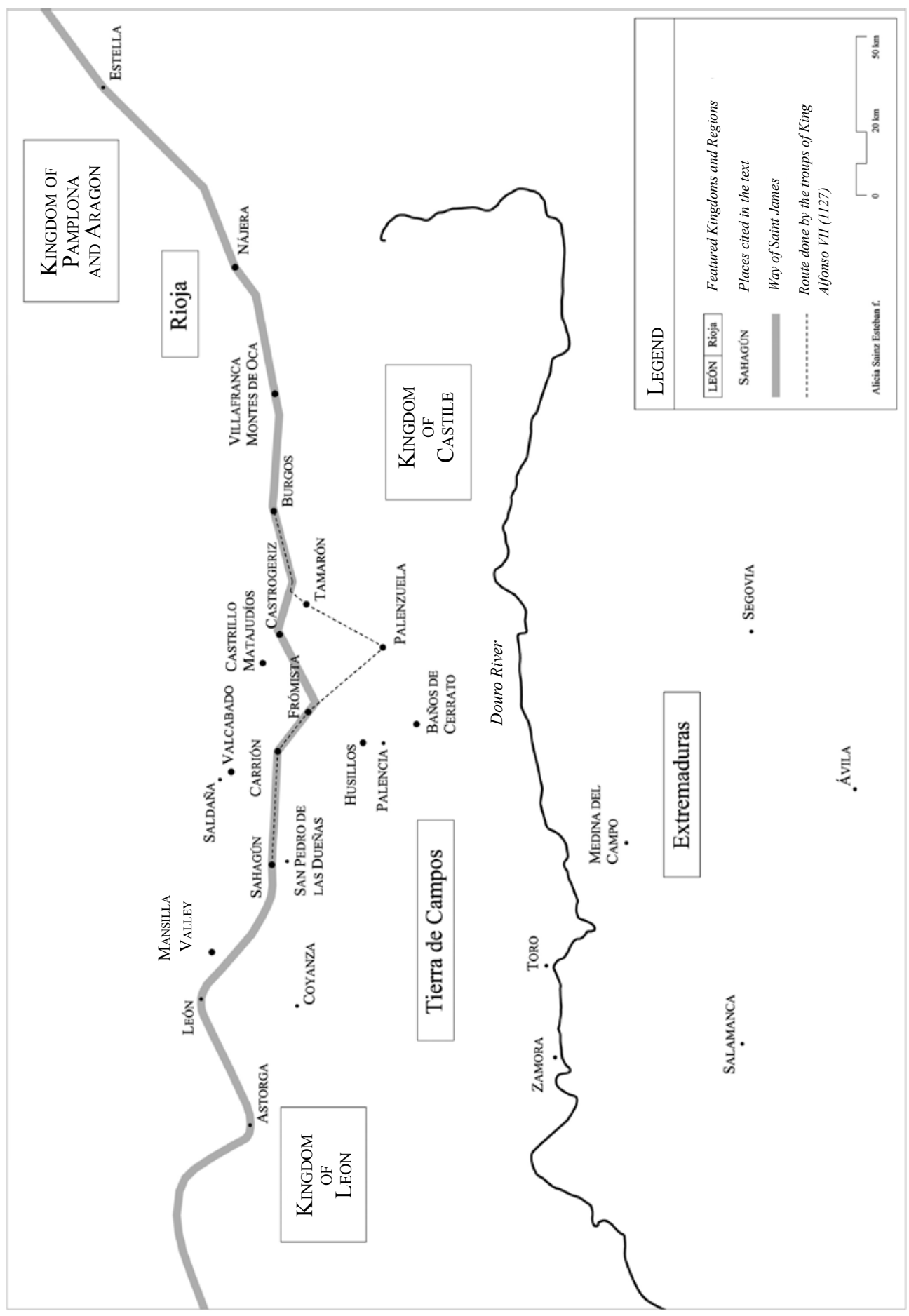


"animal" service lasted. One must not ignore that, in short, the echoes of the event forced the submission of Coyanza, another nearby rebel focus. ${ }^{42}$

The range of abuse that Pedro Díaz's men suffered suggest that the victor made the most of his victory. The defeated paid a ransom that meant renouncing all their material resources and temporarily ceding their capacity to make war. It also shows humiliation as a cultural code that differentiated between degrees of blame and left the door open for pardon. However, one perceives especially that the attitudes of humiliating, marginalising and exploiting the defeated took precedence over the most elemental, rapid and rigorous course: the violent death of the rebel (traitor) as an exercise of revenge and justice.

It is perceptible that this was also the least profitable and pedagogical path. Among other things, this was because its consequences hindered future agreements between those who perceived allegiances, alliances and rebellions as political practices. This was very different from the perspectives of a chronicler, as (formally) seduced by the providential messages as tied by his duties as a palace writer.

\footnotetext{
42. Chronica Adefonsi Imperatoris...: 160: Comes uero Rodericus, acceptis aliis militibus, alios misit in uinculis, donec redderent uniuersa bona sua, alios fecit sibi seruire multis diebus sine censu, sed illos, qui blasphemabant eum, fecit iungere cum bobus et arare et pascere herbas et bibere aquas in iacubus et comedere paleas in presepio et, expoliatis eis ex omnibus divitiis, permisit eos abire captiuos et miseros. Sed illi, qui erant in Coiancam post Semenum Enneci, hoc uidentes dederunt uillam et castellum regi.
} 